\title{
WYKORZYSTANIE MODELI RÓWNAŃ STRUKTURALNYCH DO OPISU PSYCHOLOGICZNYCH MECHANIZMÓW PODEJMOWANIA DECYZJI NA RYNKU KAPITAŁOWYM
}

Zarys treści. W ostatnich latach obserwowany jest silny wzrost zainteresowania dziedziną finansów behawioralnych. Wskazywane jest coraz większe znaczenie wpływu inklinacji behawioralnych na proces podejmowania decyzji inwestycyjnych. Artykuł dotyczy weryfikacji wybranych elementów teorii finansów behawioralnych, na podstawie badania ankietowego, z wykorzystaniem modelu równań strukturalnych (SEM). Celem artykułu jest identyfikacja i opis nieobserwowalnych inklinacji behawioralnych oraz weryfikacja hipotezy badawczej o ich wpływie na skłonność do ryzyka inwestorów indywidualnych.

Słow a kluczowe: modele równań strukturalnych (SEM), finanse behawioralne, inklinacje behawioralne, skłonność do ryzyka, analiza bootstrap.

\section{WSTĘP}

Pojęcie modelowania równań strukturalnych (SEM, Structural Equation Modeling) dotyczy klasy wielowymiarowych statystycznych modeli parametrycznych, w ramach której powiązane są ze sobą modele strukturalne i pomiarowe wyspecyfikowane na podstawie konfirmacyjnej analizy czynnikowej. Do podstawowych zalet modeli równań strukturalnych należy możliwość testowania hipotez badawczych o dużej złożoności relacji pomiędzy zmiennymi, poprzez uwzględnienie $\mathrm{w}$ modelu oprócz zmiennych obserwowalnych również zmiennych ukrytych. Ma to również niezwykle istotne znaczenie przy podjęciu 
próby identyfikacji czynników behawioralnych i złożonych współzależności zachodzących na rynku finansowym.

Terminologia, założenia oraz zależności występujące w metodyce budowy SEM rozwinięte zostały między innymi w pracach Bollena (1989), Kaplana (2000) czy Pearla (2000). W literaturze polskiej z zakresu psychologii i ekonomii o modelach SEM pisali Gatnar (2003), Brzeziński (2004), Osińska (2008), a także Konarski (2010).

W artykule podjęta została próba zastosowania modelowania równań strukturalnych w dziedzinie finansów behawioralnych, w obrębie której obserwuje się w ostatnich latach znaczący wzrost zainteresowania. Wskazywane jest coraz większe znaczenie wpływu inklinacji behawioralnych w postaci popełnianych błędów w sferze opinii i preferencji na podejmowane decyzje inwestycyjne na rynku kapitałowym. Czynniki behawioralne rozumiane są tutaj jako zmienne istotnie zakłócające podjęcie prawidłowej decyzji w procesie inwestowania. Podwaliny teoretyczne dla finansów behawioralnych wywodzą się z teorii perspektywy (Kahneman, Tversky, 1979).

Do analiz w zakresie finansów behawioralnych coraz częściej w literaturze światowej wykorzystuje się modele równań strukturalnych. Za ich pomocą thumaczony jest na przykład wpływ postrzegania ryzyka przez inwestorów na częstotliwość dokonywanych transakcji, wpływ informacji przekazywanych przez media na zachowanie inwestorów indywidualnych czy mierzony jest stopień awersji do ryzyka (Lampenius, Zickar, 2005; Wang, Shi, Fan, 2006; Hui, 2009). Pojawiajają się również analizy wykorzystujące nieliniowe modele strukturalne w aspekcie finansów behawioralnych (Lu, Song, Li, 2010).

Autorzy zakładają dwa główne cele artykułu. Pierwszym z nich jest identyfikacja czynników behawioralnych charakteryzujących błędy w sferze opinii oraz skłonność do ryzyka inwestorów indywidualnych. Drugim celem jest ustalenie siły i kierunku zależności pomiędzy wymienionymi czynnikami. Zakłada się przy tym, że część inwestorów popełnia w procesie inwestowania błędy w sferze opinii, zniekształcające otrzymywane przez nich informacje i powodujące niewłaściwe ich przetwarzanie. W związku z tym podejmują oni decyzje w oparciu o szum informacyjny. Podstawą badania jest hipoteza, że popełniane przez tę część inwestorów błędy w sferze opinii zwiększają ich skłonność do ryzyka.

\section{MODELOWANIE RÓWNAŃ STRUKTURALNYCH}

Złożona struktura zjawisk ekonomicznych, w tym finansowych, wymaga stosowania coraz bardziej wyszukanych modeli, które mogłyby precyzyjnie je odzwierciedlać. Konieczne staje się włączenie do analizy zmiennych ukrytych 
(nieobserwowalnych), na których ujęcie w modelu ekonometrycznym pozwala metodyka modelowania równań strukturalnych. Jest ona efektem połączenia konfirmacyjnej analizy czynnikowej oraz modeli przyczynowo-skutkowych stosowanych w ekonometrii. Modele równań strukturalnych są zasadniczo podobne do modeli regresji wielowymiarowej, jednak są bardziej elastyczne w przypadku opisu interakcji między zmiennymi, zwłaszcza jakościowymi, dla których nie są spełnione klasyczne założenia regresji. Są one stosowane w opisie zależności nieliniowych, skorelowanych zmiennych niezależnych, skorelowanych składników losowych oraz zmiennych ukrytych, będących wynikiem oddziaływania wielu wskaźników. Założenia o normalności rozkładu składnika losowego są analogiczne jak w modelu regresji.

Model równań strukturalnych został szczegółowo przedstawiony m.in. w pracach Bollena (1989) i Kaplana (2000). Konstrukcja modelu składa się z systemu równań opisujących powiązania pomiędzy zmiennymi ukrytymi, nazywanego modelem wewnętrznym oraz z systemu pomiaru endogenicznych i egzogenicznych zmiennych nieobserwowalnych, określanego mianem modelu zewnętrznego. Model zewnętrzny reprezentuje wyniki konfirmacyjnej analizy czynnikowej pozwalającej na wyliczenie ładunków poszczególnych czynników kształtujących zmienną ukrytą. Model wewnętrzny przedstawia analizę ścieżkową, pozwalającą na określenie zarówno bezpośrednich jak i pośrednich związków przyczynowo-skutkowych pomiędzy wcześniej wyspecyfikowanymi czynnikami.

Model wewnętrzny zwany także modelem strukturalnym ma postać

$$
\boldsymbol{\eta}=\mathbf{B} \boldsymbol{\eta}+\boldsymbol{\Gamma} \xi+\zeta
$$

gdzie:

$\boldsymbol{\eta}_{m \times 1}-$ wektor endogenicznych zmiennych ukrytych,

$\boldsymbol{\xi}_{k \times 1}$ - wektor egzogenicznych zmiennych ukrytych,

$\mathbf{B}_{m \times m}-$ macierz współczynników regresji przy zmiennych endogenicznych,

$\boldsymbol{\Gamma}_{m \times k}-$ macierz współczynników przy zmiennych egzogenicznych,

$\zeta_{m \times 1}-$ wektor składników losowych.

Model zewnętrzny zwany również modelem pomiaru jest dany jako

$$
\begin{aligned}
& \mathbf{y}=\Pi_{\mathbf{y}} \boldsymbol{\eta}+\boldsymbol{\varepsilon}, \\
& \mathbf{x}=\Pi_{\mathbf{x}} \boldsymbol{\xi}+\boldsymbol{\delta},
\end{aligned}
$$

gdzie:

$\mathbf{y}_{p \times 1}$ - wektor obserwowalnych zmiennych endogenicznych,

$\mathbf{x}_{q \times 1}$ - wektor obserwowalnych zmiennych egzogenicznych,

$\boldsymbol{\Pi}_{\mathbf{y}}, \boldsymbol{\Pi}_{\mathbf{x}}-$ macierze ładunków czynnikowych,

$\boldsymbol{\varepsilon}_{p \times 1}, \boldsymbol{\delta}_{q \times 1}-$ wektory błędów pomiaru. 
Wśród sposobów estymacji modeli SEM wyróżnia się metodę największej wiarygodności (MNW), uogólnioną metodę najmniejszych kwadratów (UMNK) oraz metody asymptotycznie niewrażliwe na rozkład (ADF). Wybór właściwej metody zależy od rodzaju danych, rozmiaru próby i rozkładów zmiennych. Metodę największej wiarygodności stosować można tylko dla wielowymiarowego rozkładu normalnego. W przypadku, gdy rozkład nie spełnia tego warunku stosuje się metodę ADF, wymagającą próby liczącej co najmniej 200-500 obserwacji lub UMNK, dla której wymagana jest duża próba o liczebności powyżej 2500 obserwacji (Konarski, 2010).

Oszacowany model należy zweryfikować pod względem stopnia dopasowania i istotności parametrów. Kryteria oceny jakości modeli ścieżkowych nie są jednoznaczne, jednak w opracowaniach można znaleźć pewne wskazówki w tym zakresie (Bollen, 1989; Kaplan, 2000). Na ogół proponuje się wykorzystanie całego zestawu wskaźników, które są w bardzo szerokim zestawie wyznaczane przy zastosowaniu oprogramowania dedykowanego SEM.

Stopień dopasowania modelu równań strukturalnych określa się najczęściej poprzez porównanie otrzymanego modelu z dwoma skrajnymi modelami, tj. nasyconym i niezależnym. Wśród miar stopnia dopasowania modelu SEM za najważniejsze przyjmuje się miary porównujące estymowany model z modelem bazowym, tj. współczynniki IFI, TFI, RFI, NFI, CFI oraz średniokwadratowy błąd aproksymacji RMSEA.

Indeks IFI (Incremental Fit Index), uznawany za podstawowy, określony jest wzorem:

gdzie:

$$
I F I=\frac{T_{b}-T_{h}}{T_{b}-d f_{h}}
$$

$T_{h}$ - statystyka chi-kwadrat estymowanego modelu,

$T_{b}$ - statystyka chi-kwadrat modelu niezależnego,

$d f_{h}$ - liczba stopni swobody estymowanego modelu.

Wartości wskaźnika IFI powinny zawierać się w przedziale $<0 ; 1>$, przy czym model uznaje się za dobrze dopasowany, jeśli wartość tego współczynnika jest większa od 0,95. W pracy Bollena (1989) zalecane jest również wykorzystanie wskaźników TFI, RFI, NFI, CFI, których wyliczanie jak i interpretacja opiera się na zasadzie podobnej do $I F I$.

Dla oceny modelu SEM wykorzystuje się powszechnie wskaźnik RMSEA (Root Mean Square Error of Approximation). W przeciwieństwie do opisywanej miary IFI, podczas obliczania wskaźnika RMSEA nie następuje porównywanie modelu estymowanego z modelem bazowym. Wskaźnik ten oblicza się według wzoru: 
gdzie:

$$
R M S E A=\sqrt{\frac{T_{h}-d f_{h}}{(N-1) d f_{h}}},
$$

$\mathrm{N}$ - oznacza liczbę obserwacji, zaś pozostałe oznaczenia są analogiczne jak we wzorze (4).

Im niższa wartość wskaźnika RMSEA wyliczonego na podstawie modelu, tym lepszy stopień dopasowania modelu. Przyjmuje się, że dla wartości RMSEA mniejszej od 0,1 model jest dobrze dopasowany do danych. Niekiedy wartość graniczną ustala się na poziomie 0,05 (Kline, 2005).

\section{PODSTAWOWE MODELE FINANSÓW BEHAWIORALNYCH}

Teorię finansów behawioralnych rozwinęli przede wszystkim w latach siedemdziesiątych dwudziestego wieku Tversky i Kahneman w pracy opublikowanej w 1979 roku. Wyodrębnili oni trzy podstawowe heurystyki, czyli strategie, poprzez które jednostki zawężają zbiór możliwości w celu podjęcia odpowiedniej decyzji.

Pierwszą z nich jest heurystyka dostępności, polegająca na poszukiwaniu w pamięci lub wyobraźni faktów podobnych, co powoduje dostrzeganie iluzorycznych korelacji i związków o charakterze przyczynowo-skutkowym. Kolejną inklinacją jest heurystyka reprezentatywności oznaczająca wnioskowanie na temat całej populacji na podstawie niewielkiej próby, co wpływa na powstanie błędu koniunkcji (przypisywanie większego prawdopodobieństwa koniunkcjom zdarzeń niż zdarzeniom pojedynczym), czy błędu polegającego na oczekiwaniu powrotu procesu do wartości średniej. Ostatnią - trzecią jest heurystyka zakotwiczenia i dostosowania, polegająca na nieuzasadnionym zwracaniu uwagi na wartości arbitralne, początkowo zasugerowane.

Podstawową przesłankę do rozważań na temat funkcjonowania rynku kapitałowego $\mathrm{w}$ aspekcie finasów behawioralnych stanowią występujące na nim wszelkiego rodzaju anomalie przeczące jego efektywności. Anomalie występujące na rynku kapitałowym, takie jak niczym nieuzasadnione nadmierne obroty giełdowe, efekt kalendarza, poinformacyjny dryf ceny, czy dodatnie krótkoterminowe korelacje stóp zwrotu akcji opisywane były m.in. w pracach Frencha (1980); Rendlemana (1982); Haugena (1988); Szyszki (2003). Klasyczne teorie finansów nie są w stanie wyjaśnić wyżej wymienionych zjawisk, gdyż inwestorzy nie zawsze podejmują swoje decyzje w sposób racjonalny stosując instrumenty analizy technicznej czy fundamentalnej. 
Teoria finansów behawioralnych tłumaczy niedostateczne lub nadmierne reakcje cen na informacje wykorzystując aspekty psychologiczne inwestorów, dotyczące formułowanych przez graczy giełdowych opinii i posiadanych preferencji. Tworząc różnego rodzaju modele behawioralne podejmuje ona próbę wyjaśnienia decyzji inwestycyjnych za pomocą indywidualnych oraz społecznych skłonności poznawczych i emocjonalnych.

Przełomową w tym zakresie okazała się praca Longa, Shleifera, Summersa i Waldmanna (1990), w której autorzy podjęli sie wyjaśnienia przyczyn nieracjonalnego dyskonta w notowaniu jednostek zamkniętych funduszy inwestycyjnych. Dzieląc inwestorów na racjonalnych, podejmujących decyzje w oparciu o prawidłowo przeprowadzoną analizę fundamentalną i nieracjonalnych, kierujących się szumem informacyjnym pokazali oni, iż racjonalni uczestnicy rynku potrzebują dyskonta, które pozwalałoby im zrekompensować zwiększone ryzyko wahań notowań, wynikające ze złej wyceny jednostek przez inwestorów nieracjonalnych.

Zakłada się, że inwestorzy racjonalni podejmują swe decyzje na podstawie właściwych sygnałów płynących z rynku, które jednocześnie interpretują w sposób prawidłowy, właściwie dokonując wyceny i oceny ryzyka. Z kolei inwestorów bazujących na szumie informacyjnym (noise traders) charakteryzują przede wszystkim błędne oczekiwania co do wariancji zwrotu. Z tego względu dokonują oni błędnej wyceny portfela, a w związku z tym i oceny jego ryzyka. Wynika to $\mathrm{z}$ faktu, iż podejmując decyzje podlegają inklinacjom behawioralnym, przez co niepoprawnie interpretują zdarzenia, a w konsekwencji podejmują decyzje błędne bądź też opierające się na informacjach nieistotnych dla konstrukcji i analizy portfela. Powoduje to, że są oni w stanie podjąć większe ryzyko przy tym samym poziomie zasobów i awersji do ryzyka co inwestorzy racjonalni. Jednocześnie ponoszone wyższe ryzyko i popełnione błędy jest rekompensowane przez nich większą częstotliwością zmian dokonywanych w potfelu.

Błędne wyobrażenia inwestorów nieracjonalnych dotyczące wariancji są wynikiem systematycznych błędów wnioskowania, które mają swe psychologiczne podłoże i wynikają ze stosowanych przez nich heurystyk. Mimo, iż heurystyki owe z jednej strony pomagają inwestorowi przebrnąc przez natłok informacji, to $\mathrm{z}$ drugiej, zniekształcają proces podejmowania decyzji poprzez nadmierną pewność siebie i własnej wiedzy, złudzenie kontroli nad obserwowanymi zjawiskami, nadmierny optymizm, interpretowanie informacji w taki sposób, by potwierdzić wcześniejsze opinie (pułapka potwierdzenia), efekt myślenia wstecznego, dysonans poznawczy, selektywną percepcję oraz inne (Zaleśkiewicz, 2003; Zielonka, 2006). Wymienione aspekty składają się na podejmowane przez inwestorów błędy zarówno w sferze opinii jak i preferencji. Dodatkowo w procesie podejmowania decyzji przez jednostkę występują pewne ograniczenia czasowe 
i ograniczenia technologiczne. Wszystko to powoduje, iż zamiast założenia o racjonalności stosowanego przez teorię neoklasyczną, należy raczej przyjąć pojęcie ograniczonej racjonalności inwestorów (Dzik, Tyszka, 2004).

Cztery lata po opublikowaniu pracy Longa, Shleifera, Summersa i Wald-manna (1990) w pracy Lakonishoka, Schleifera i Vishny'ego (1994) opracowany został model LSV. Autorzy analizując za jego pomocą dane za okres 1968-1990 wykazali, iż ponadprzeciętny wzrost cen akcji dochodowych, o niskich wartościach wskaźników fundamentalnych, był wynikiem nadmiernej wiary inwestorów w utrzymywanie się dotychczasowego trendu dobrych wyników finansowych i zbyt późnego dostrzeżenia sygnałów świadczących o zmianie tej tendencji. Autorzy wskazali przy tym, iż błędy te dotyczyły nie tylko inwestorów indywidualnych, ale także instytucjonalnych.

W kolejnej pracy Barberisa, Schleifera i Vishny'ego (1998) przedstawiono model BSV, w którym poinformacyjny dryf cen wyjaśniany jest za pomocą pojęć konserwatyzmu inwestorów (przekonanie o powrocie do średniej) oraz heurystki reprezentatywności (przekonanie o kontynuacji trendu).

Z kolei Dacey i Zielonka (2005) zaproponowali deskryptywny model finansów behawioralnych. Przyjęto w nim założenie, iż inwestorzy maksymalizując subiektywną oczekiwaną wartość popełniają dwa rodzaje błędów. Pierwszy z nich polega na złym oszacowaniu prawdopodobieństwa wystąpienia danego zdarzenia, co jest spowodowane uleganiem różnego rodzaju heurystykom. Drugi błąd polega na zaniżaniu dużych wartości prawdopodobieństw i zawyżaniu małych przez inwestorów.

W dalszej części opracowania rozpatrywane są empiryczne fakty dotyczące błędów w sferze opinii polegających na niepoprawnej interpretacji informacji docierających z rynku, co przedkłada się na niewłaściwe decyzje inwestycyjne podejmowane przez inwestorów indywidualnych na polskim rynku giełdowym.

\section{ANALIZA EMPIRYCZNA MECHANIZMÓW BEHAWIORALNYCH PODEJMOWANIA DECYZJI PRZEZ INWESTORÓW INDYWIDUALNYCH}

W celu przeprowadzenia empirycznej analizy mechanizmów podejmowania decyzji na rynku kapitałowym przygotowany został kwestionariusz, zawierający pytania dotyczące popełnianych przez inwestorów błędów w sferze opinii oraz pytania mające określić ich skłonność do ryzyka. Ankietę przeprowadzono w 2010 r. na próbie 144 respondentów, złożonej z rzeczywistych i potencjalnych inwestorów indywidualnych na polskim rynku kapitałowym. Uzyskane wyniki stanowiły wstęp do dalszego, pogłębionego badania. Zawarte w kwestionariuszu 
pytania miały charakter zamknięty, jednokrotnego wyboru, zaś wszystkie uzyskane odpowiedzi oparte były na pięciostopniowej skali porządkowej.

Opierając się na wspomnianym w punkcie poprzednim artykule Longa, Shleifera, Summersa i Waldmanna (1990) zbudowano hipotetyczny model SEM mający na celu weryfikację postawionej na wstępie hipotezy, zgodnie z którą oczekuje się, że inwestorzy popełniający błędy w sferze opinii, a więc bazujący na szumie informacyjnym, cechują się większą skłonnością do ryzyka, niż inwestorzy racjonalni. Hipotetyczny model SEM, będący zapisem powyższej hipotezy w formie układu równań podlegającego estymacji, podzielony został na model zewnętrzny oraz model wewnętrzny.

Model zewnętrzny określony został za pomocą równań

$$
\begin{aligned}
& x_{1}=\beta_{1} \xi_{1}+\delta_{1}, x_{2}=\beta_{2} \xi_{1}+\delta_{2}, x_{3}=\beta_{3} \xi_{1}+\delta_{3}, \\
& y_{1}=\beta_{4} \eta_{1}+\varepsilon_{1}, y_{2}=\beta_{5} \eta_{1}+\varepsilon_{2}, y_{3}=\beta_{6} \eta_{1}+\varepsilon_{3}, y_{4}=\beta_{7} \eta_{1}+\varepsilon_{4},
\end{aligned}
$$

natomiast model wewnętrzny (rekursywny) opisany jest równaniem

$$
\eta_{1}=\alpha_{1} \xi_{1}+\zeta_{1}
$$

gdzie:

$x_{1}, x_{2}, x_{3}, y_{1}, y_{2}, y_{3}, y_{4},-$ stanowią zmienne obserwowalne manifestujące czynniki,

$\eta_{1}$ - endogeniczna zmienna ukryta reprezentująca skłonność do ryzyka,

$\xi_{1}$ - egzogeniczna zmienna ukryta określająca popełniane przez inwestorów błędy w sferze opinii,

$\delta_{i}, \varepsilon_{i}, \zeta_{i}-$ są to składniki losowe modeli.

Równanie (7) zawiera tylko bezpośredni wpływ błędów w sferze opinii na skłonność do ryzyka. Pytania kwestionariusza, na podstawie których wytypowane zostały zmienne obserwowalne charakteryzujące poszczególne czynniki zestawiono w tabeli 1.

W procesie estymacji modelu zidentyfikowane zostały czynniki charakteryzujące postawy inwestorów indywidualnych, które jako zmienne ukryte odzwierciedlać mają popełniane błędy w sferze opinii oraz skłonność do ryzyka. Na podstawie przeprowadzonej ankiety wykonano konfirmacyjną analizę czynnikową, w wyniku czego wyodrębniono dwa wymienione wcześniej czynniki ${ }^{1}$.

1 Przez identyfikację czynników przy pomocy analizy konfirmacyjnej rozumie się fakt, iż autorzy uprzednio przyjęli na podstawie dostępnej literatury i istniejących badań pewien określony zbiór czynników charakteryzujący daną zmienną niemierzalną. Zadaniem analizy konfirmacyjnej było potwierdzenie hipotez dotyczących czynników, a także oszacowanie ładunków czynnikowych poszczególnych zmiennych. 
Tabela 1. Zestawienie wykorzystanych pytań kwestionariusza przeprowadzonej ankiety

\begin{tabular}{|c|l|c|l|}
\hline \multicolumn{2}{|c|}{$\eta_{1}$-skłonność do ryzyka } & \multicolumn{2}{|c|}{$\xi_{1}$ - błędy w sferze opinii } \\
\hline Zm. & \multicolumn{1}{|c|}{ Pytanie } & Zm. & \multicolumn{1}{|c|}{ Pytanie } \\
\hline$y_{1}$ & $\begin{array}{l}\text { Czy zdarza Ci się wybrać drogę na } \\
\text { skróty? }\end{array}$ & $x_{1}$ & $\begin{array}{l}\text { Załóżmy, że złożony przez Ciebie wniosek na } \\
\text { rozpoczęcie działalności gospodarczej otrzymał } \\
\text { dotację w sumie 50000 złotych. Jakie jest, według } \\
\text { Ciebie, prawdopodobieństwo osiągnięcia sukcesu } \\
\text { w nowym przedsięwzięciu? }\end{array}$ \\
\hline$y_{3}$ & $\begin{array}{l}\text { Czy zgadzasz się ze stwierdzeniem, } \\
\text { że postępujesz bardziej ryzykownie } \\
\text { od innych? }\end{array}$ & $x_{2}$ & $\begin{array}{l}\text { Wysyłając kupon Totolotka, który ze scenariuszy } \\
\text { uważasza za najbardziej prawdopodobny? }\end{array}$ \\
\hline$y_{3}$ & $\begin{array}{l}\text { Czy zgadzasz się ze stwierdzeniem: } \\
\text { Choć wiem co mi szkodzi, nie } \\
\text { unikam tego? }\end{array}$ & $x_{3}$ & $\begin{array}{l}\text { Z informacji dochodzących z rynku wynika, } \\
\text { że inwestycja w akcje spółki X zapewni co najmniej } \\
\text { 50\% zysku w okresie dwóch miesięcy. Czy } \\
\text { przyjmując obecną wartość twoich inwestycji na } \\
\text { poziomie 10000 złotych przy potencjalnej mniejszej } \\
\text { stopie zysku, gotowy jesteś na sprzedaż części } \\
\text { swojego portfela oraz zakup akcji spółki X? }\end{array}$ \\
\hline$y_{4}$ & $\begin{array}{l}\text { Czy zgadzasz się ze stwierdzeniem: } \\
\text { Jeśli ktoś zrobi coś ryzykownego, to } \\
\text { mam ochotę zrobić coś podobnego? }\end{array}$ & \multicolumn{2}{|l}{} \\
\hline
\end{tabular}

Źródło: Opracowanie własne

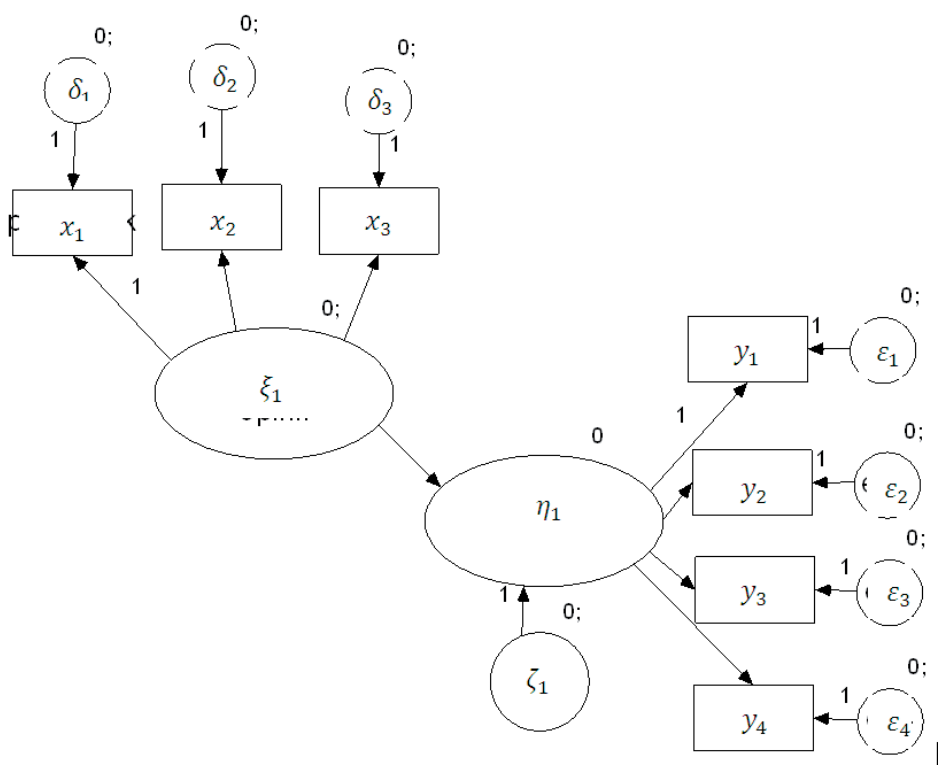

Rysunek 1. Schemat modelu równań strukturalnych będącego ilustracją postawionej hipotezy

Źródło: opracowanie własne 
Na rysunku 1 zaprezentowany został schemat hipotetycznego modelu SEM, a wyniki oszacowania modelu metodą największej wiarygodności, mającego zweryfikować postawioną na wstępie hipotezę przy wykorzystaniu zebranych danych ankietowych, zaprezentowano w tabeli 2 . W tabeli 3 zawarto miary stopnia dopasowania uzyskanego modelu.

Tabela 2. Oszacowane parametry modelu wewnętrznego i zewnętrznego ${ }^{2}$

\begin{tabular}{|c|c|c|c|c|}
\hline Zależność & Parametr & Ocena & Błąd stand. & Wartość $p$ \\
\hline$x_{1}<-\xi_{1}$ & $\beta_{1}$ & 0,382 & - & - \\
\hline$x_{2}<-\xi_{1}$ & $\beta_{2}$ & 0,545 & 0,815 & 0,008 \\
\hline$x_{3}<-\xi_{1}$ & $\beta_{3}$ & 0,391 & 0,493 & 0,015 \\
\hline$y_{1}<-\eta_{1}$ & $\beta_{4}$ & 0,337 & - & - \\
\hline$y_{2}<-\eta_{1}$ & $\beta_{5}$ & 0,690 & 0,831 & 0,003 \\
\hline$y_{3}<-\eta_{1}$ & $\beta_{6}$ & 0,406 & 0,509 & 0,009 \\
\hline$y_{4}<-\eta_{1}$ & $\beta_{7}$ & 0,538 & 0,748 & 0,004 \\
\hline$n_{1}<-\xi_{1}$ & $\alpha_{1}$ & 0,697 & 0,333 & 0,036 \\
\hline
\end{tabular}

Źródło: opracowanie własne

Tabela 3. Miary dopasowania modelu

\begin{tabular}{|c|c|c|}
\hline Model & IFI & RMSEA \\
\hline Estymowany & 0,999 & 0,006 \\
\hline Nasycony & 1 & - \\
\hline Niezależny & 0,000 & 0,128 \\
\hline
\end{tabular}

Źródło: opracowanie własne

Wyniki opracowania modelu zewnętrznego zawarte w tabeli 2 wskazują, że wszystkie ładunki czynnikowe są statystycznie istotne i przyjmują wartości powyżej 0,33 . Zmienne $x_{1}, x_{2}, x_{3}$ składają się na czynnik opisujący błędy w sferze opinii popełniane przez inwestorów, zaś zmienne $y_{1}, y_{2}, y_{3}, y_{4}$ - na czynnik

2 Zgodnie z założeniami konfirmacyjnej analizy czynnikowej, w przypadku parametrów $\beta_{1}, \beta_{4}$ przyjęto wartości stałe i nie były one estymowane. 
reprezentujący ich skłonność do ryzyka. Tabela 2 zawiera w ostatnim wierszu wyniki estymacji modelu wewnętrznego. Ocena parametru na poziomie 0,697 oraz jego istotność statystyczna wskazuje na silny wpływ popełnianych błędów w sferze opinii na wzrost skłonności do ryzyka wśród inwestorów indywidualnych. Potwierdza to postawioną we wstępie hipotezę badawczą. Zgodnie z zawartymi w kwestionariuszu pytaniami, na błędy w sferze opinii składają się przede wszystkim pytania dotyczące złudzenia kontroli oraz nadmiernego optymizmu inwestorów. Popełnianie przez inwestorów błędy oznaczają nieumiejętność wyciągania poprawnych wniosków z zaobserwowanych faktów. W związku z tym częściej podejmowane są działania ryzykowne, gdyż inwestorzy nie są w stanie oszacować w pełni stopnia ponoszonego ryzyka, co skutkuje brakiem racjonalności w postępowaniu.

Wartość wskaźnika IFI jest równa 0,999 , a wartość $R M S E A$ na poziomie 0,006 , co pozwala stwierdzić, iż przedstawione miary potwierdzają dobre dopasowanie modelu do danych.

\section{ANALIZA BOOTSTRAP}

Spełnienie wymogu dotyczącego wielowymiarowego rozkładu normalnego pozwalającego na estymację modelu SEM metodą MNW jest w praktyce trudne do osiągnięcia. W pracach Efrona (1982), a także Kotza i Johnsona (1992) przedstawione zostały teoretyczne podstawy procedury bootstrap. Procedura ta polega na losowaniu wielu podróbek na podstawie oryginalnych danych, co pozwala na sprawdzenie empirycznego rozkładu parametrów w odniesieniu do każdej z uzyskanych próbek. Może ona zostać wykorzystana do wnioskowania w zakresie modelu SEM zwiększając wiarygodność uzyskanych wyników.

Na podstawie posiadanych danych zastosowano bootstrap dla 2000 próbek, przy użyciu estymatora największej wiarygodności. Wykonanie procedury pozwoliło na otrzymanie nowych ocen parametrów, które stanowią średnie z ocen uzyskanych dla wszystkich próbek. Otrzymane wyniki przedstawiono w tabeli 4, przy czym dwie pierwsze kolumny zawierają oceny parametrów i błędy standardowe obliczone wcześniej na podstawie metody największej wiarygodności. Kolejne dwie kolumny zawierają uzyskane średnie dla poszczególnych ocen parametrów na podstawie procedury bootstrap i ich błędy standardowe. Porównanie pierwotnych ocen parametrów ze średnimi wskazuje na istnienie obciążenia estymatora. Największe obciążenie występuje w przypadku modelu wewnętrznego (parametr $\alpha_{1}$ ) i wynosi 0,151 . Spowodowane jest to małą wielkością próby, zatem można przypuszczać, że wraz ze wzrostem jej liczebności obciążenie uległoby zmniejszeniu. 
Tabela 4. Wyniki analizy bootstrap

\begin{tabular}{|c|c|c|c|c|c|c|}
\hline \multirow{2}{*}{ Zależność } & \multicolumn{2}{|c|}{ MNW } & \multicolumn{4}{c|}{ Bootstrap } \\
\cline { 2 - 7 } & $\begin{array}{c}\text { Ocena } \\
\text { parametru }\end{array}$ & Błąd stand. & $\begin{array}{c}\text { Średnia ocena } \\
\text { parametru }\end{array}$ & Błąd stand. & Obciążenie & $\begin{array}{c}\text { Błąd stand. } \\
\text { obciążenia }\end{array}$ \\
\hline$\eta_{1}<-\xi_{1}$ & 0,696 & 0,331 & 0,847 & 0,797 & 0,151 & 0,018 \\
\hline$x_{1}<-\xi_{1}$ & 0,382 & - & 0,392 & 0,156 & 0,010 & 0,003 \\
\hline$x_{2}<-\xi_{1}$ & 0,545 & 0,815 & 0,546 & 0,160 & 0,001 & 0,004 \\
\hline$x_{3}<-\xi_{1}$ & 0,392 & 0,493 & 0,380 & 0,132 & $-0,012$ & 0,003 \\
\hline$y_{1}<-\eta_{1}$ & 0,336 & - & 0,328 & 0,113 & $-0,008$ & 0,003 \\
\hline$y_{2}<-\eta_{1}$ & 0,690 & 0,831 & 0,685 & 0,131 & $-0,005$ & 0,003 \\
\hline$y_{3}<-\eta_{1}$ & 0,407 & 0,509 & 0,406 & 0,109 & $-0,001$ & 0,002 \\
\hline$y_{4}<-\eta_{1}$ & 0,541 & 0,748 & 0,546 & 0,111 & 0,005 & 0,002 \\
\hline
\end{tabular}

Źródło: opracowanie własne

Tabela 5. Przedziały ufności dla parametrów

\begin{tabular}{|c|c|c|c|c|}
\hline Zależność & Ocena & Dolna granica & Górna granica & Wartość $p$ \\
\hline$\eta_{1}<-\xi_{1}$ & 0,696 & 0,187 & 3,209 & 0,001 \\
\hline$x_{1}<-\xi_{1}$ & 0,382 & 0,082 & 0,670 & 0,002 \\
\hline$x_{2}<-\xi_{1}$ & 0,545 & 0,287 & 0,910 & 0,001 \\
\hline$x_{3}<-\xi_{1}$ & 0,392 & 0,137 & 0,656 & 0,003 \\
\hline$y_{1}<-\eta_{1}$ & 0,336 & 0,101 & 0,547 & 0,001 \\
\hline$y_{2}<-\eta_{1}$ & 0,690 & 0,464 & 0,987 & 0,001 \\
\hline$y_{3}<-\eta_{1}$ & 0,407 & 0,169 & 0,604 & 0,001 \\
\hline$y_{4}<-\eta_{1}$ & 0,541 & 0,307 & 0,740 & 0,002 \\
\hline
\end{tabular}

Źródło: opracowanie własne

Tabela 5 zawiera granice przedziałów ufności dla parametrów modelu SEM przy 95\% poziomie ufności, utworzone z uwzględnieniem obliczonego obciążenia. W kolumnie ocena, zamieszczone zostały oceny parametrów uzyskane na podstawie metody największej wiarygodności. W kolumnach dolna i górna granica zamieszczono skorygowane granice przedziałów. Ponadto uwzględniając istniejące obciążenie ocen parametrów, sprawdzono ponownie ich istotność statystyczną. W ostatniej kolumnie zawarte są wartości p testu na istotność 
parametrów. Wartości te wskazują na istotność statystyczną wszystkich parametrów modelu SEM. Można zatem stwierdzić, iż procedura bootstrap pozwoliła na potwierdzenie istotności oszacowanych parametrów modelu, przy wykorzystaniu małej próby.

\section{PODSUMOWANIE}

W artykule przedstawiono analizę zachowań inwestorów indywidualnych z wykorzystaniem modelu równań strukturalnych. Na potrzeby badania utworzony został hipotetyczny model SEM, w którym uwzględniono czynniki charakteryzujące błędy inwestorów indywidualnych w sferze opinii oraz ich skłonność do ryzyka. Zgodnie z postawioną hipotezą, w modelu uwzględniono wpływ inklinacji behawioralnych na skłonność do ryzyka. Na bazie teorii finansów behawioralnych zbudowano kwestionariusz i przeprowadzono ankietę, której wyniki posłużyły do estymacji i weryfikacji hipotetycznego modelu SEM. Estymacja oraz weryfikacja modelu pozwoliła na identyfikację wyróżnionych czynników u respondentów oraz potwierdzenie istotnego wpływu popełnianych błędów w sferze opinii na wzrost skłonności do ryzyka wśród inwestorów podejmujących decyzje w oparciu o szum informacyjny. Wyniki przeprowadzonego badania okazały się zgodne z wnioskami zawartymi w pracy Longa, Shleifera, Summersa i Waldmanna (1990). Ze względu na małą liczebność próby przeprowadzono dodatkowo procedurę bootstrap, której wyniki potwierdziły statystyczną poprawność uzyskanego modelu i słuszność sformułowanych wniosków.

\section{LITERATURA}

Barberis N., Shleifer A. Vishny R. (1998), A model of investor sentiment, „Journal of Financial Economics", 49, 307-343.

Bollen K. A. (1989), Structural Equations with Latent Variables, Wiley.

Brown T.A. (2006), Confirmatory Factor Analysis for Applied Research, Guilford Press. Brzeziński J. (2004), Metodologia badań psychologicznych. Wybór tekstów, PWN, Warszawa.

Dzik B., Tyszka T. (2004), Problem racjonalności podmiotów ekonomicznych, [w:] Tyszka T. (red.), Psychologia ekonomiczna, Gdańskie Wydawnictwo Psychologiczne, Gdańsk.

Efron B. (1979), Bootsrap methods: Another look at the jackknife, „Annals of Statistic”, $7,1-26$.

French K. R. (1980), Stock Returns and the Weekend Effe ct, „Journal of Financial

Economics", 8, 55-69. 
Gatnar E. (2003), Statystyczne modele struktury przyczynowej zjawisk ekonomicznych, Akademia Ekonomiczna, Katowice.

Haugen R., Lakonishok J. (1988), The Incredible January Effect, Dow-Jones Irwin, Homewood.

Hui H. (2009), Effect of Financial News on Investors - Trading Behavior, City University of Honk Kong, working paper.

Kahneman D., Tversky A. (1979), Prospect Theory: An Analysis of Decision under Risk, "Econometrica", XLVII, 263-291.

Kaplan D. (2000), Structural Equation Modeling: Foundations and Extensions, Sage Publications.

Kline R. B. (2005), Principles and Practice of Structural Equation Modeling, The Guilford Press.

Kotz S., Johnson N.I. (1992), Breakthrough in statistics, Springer-Verlag, New York.

Konarski R. (2010), Modele równań strukturalnych. Teoria i praktyka, PWN, Warszawa.

Lakonishok J., Shleifer A., Vishny R. (1994), Contrarian Investment, Extrapolation, and Risk, ,Journal of Finance”, 49, 1541-1578.

Lampenius N., Zickar M. J. (2005), Development and Validation of a Model and Measure of Financial Risk-Taking, „The Journal of Behavioral Finance”, 6 (3), 129-143.

Long J. B., Shleifer A., Summers L.H., Waldmann R.J. (1990), Noise Trader Risk in Financial Markets, „Journal of Political Economy”, University of Chicago Press, 98 (4), 703-738.

Lu B., Song X. Y., Li X. D. (2010), Bayesian analysis of multi-group nonlinear structural equation models with application to behavioral finance, „Quantitative Finance”, $10(2), 1-12$.

Osińska M. (2008), Ekonometryczna analiza zależności przyczynowych, Uniwersytet Mikołaja Kopernika, Toruń.

Pearl J. (2000), Causality. Models, reasoning and inference, Cambrige.

Rendleman R., Jones C., Latane H. (1982), Empirical Anomalies Based on Unexpected Earnings and the Importance of Risk Adjustments, "Journal of Financial Economics", 10 (3), 269-287.

Szyszka A. (2003), Efektywność giełdy papierów wartościowych w Warszawie na tle rynków dojrzatych, Akademia Ekonomiczna.

Wang X. L., Shi K., Fan H. X. (2006), Chinese Stock Markets, psychological mechanisms, investment behaviors, risk perception, individual investors, „Journal of Economic Psychology", 27 (6), 762-780

Zaleśkiewicz T. (2003), Psychologia inwestora giełdowego. Wprowadzenie do behawioralnych finansów, Gdańskie Wydawnictwo Psychologiczne, Gdańsk.

Zielonka P. (2006), Behawioralne aspekty inwestowania na rynku papierów wartościowych, CeDeWu, Warszawa. 


\title{
STRUCTURAL EQUATION MODEL AS A TOOL OF ANALYSIS OF PSYCHOLOGICAL MECHANISMS OF DECISION-MAKING PROCESS AT CAPITAL MARKET
}

\begin{abstract}
In the last years, mainly in the period of the financial crisis, a raising interest in behavioural finance could be observed. It has been pointed out that behavioural inclinations strongly influence the process of decision-making at capital market. The behavioural factors are understood here as noisy variables that disturb a process of proper investment decision-making. The paper concerns the verification of chosen elements of the behavioural finance theory on the basis of polling, with application of a structural equation model (SEM). The purpose of the paper is to identify and to describe the possible behavioural inclinations as well as to verify the hypothesis of that how much they influence the individual investors' risk propensity.
\end{abstract}

Key words: structural equation model (SEM), behavioural finance, behavioural inclinations, risk propensity, bootstrap. 
